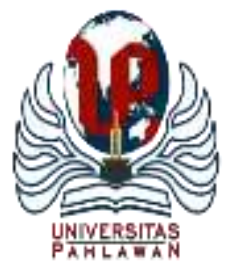

Edukatif : Jurnal Ilmu Pendidikan Volume 4 Nomor 1 Tahun 2022 Halm 101 - 106 EDUKATIF: JURNAL ILMU PENDIDIKAN

Research \& Learning in Education

https://edukatif.org/index.php/edukatif/index

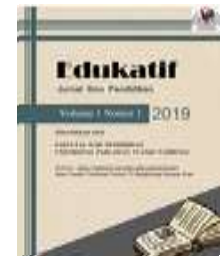

\title{
A Study of Online Platforms Learning During the Covid-19 Pandemic in College
}

\author{
Syahraini Ritonga $^{1 凶}$, Witma Novita Atnur $^{2}$, Erlia Utami Panjaitan ${ }^{3}$, Defri Rahmat ${ }^{4}$, \\ Rahmi Syafriyeti ${ }^{5}$ \\ Universitas Al Washliyah Labuhanbatu, Indonesia ${ }^{1,2,3,4,5}$ \\ E-mail : syahraini.rtg@gmail.com ${ }^{1}, \underline{\text { atnurwitma@gmail.com }}^{2}, \underline{\text { erlpanjaitan} 90 @ g m a i l . c o m}^{3}$, \\ $\underline{\text { defrirahmat28@gmail.com }}^{4}, \underline{\text { rahmi@univalabuhanbatu.ac.id }}^{5}$
}

\begin{abstract}
Abstrak
Sejak pandemi COVID-19 dimulai, hampir satu miliar orang telah dikarantina untuk mencegah penyebaran virus. Akibatnya dibanyak negara, seperti Indonesia, memberlakukan undang-undang yang melarang semua jenis pendidikan dan memaksa pemerintah dan lembaga terkait untuk mempersiapkan metode pembelajaran alternatif pada setiap Lembaga pendidikan. Di sisi lain, perguruan tinggi yang belum membuat infrastruktur pembelajaran online mungkin menghadapi kesulitan. Banyak dosen dan mahasiswa yang ragu untuk menerapkan strategi pembelajaran online karena budaya sistem Pendidikan lama. Tujuan penelitian ini adalah mengetahui bagaimana kegiatan belajar mengajar yang dilaksanakan setahun setelah Universitas Al Washliyah Labuhanbatu ditutup karena wabah. Penelitian ini menggunakan pendekatan metode campuran yang mencakup informasi kuantitatif dan kualitatif melalui penggunaan kuesioner. Teknik metode campuran dikombinasikan dengan kuesioner online yang disiapkan menggunakan Google Forms dan dibagikan kepada 100 siswa. Lebih dari 75\% dosen menggunakan konferensi video, sistem manajemen pembelajaran, dan pesan instan dalam kuliah mereka. Selama Covid-19 di Universitas Al Washliyah, Para dosen sepakat bahwa menggunakan campuran dari ketiga platform tersebut membantu mengurangi hambatan untuk pembelajaran online sehingga dosen maupun mahasiswa semakin nyaman dengan penggunaan sumber belajar online.
\end{abstract}

Kata Kunci: COVID-19, pandemic, pembelajaran daring

Abstract

Nearly a billion individuals have been quarantined since the COVID-19 epidemic began. As a result, several nations, including Indonesia, have enacted legislation prohibiting all forms of schooling and requiring governments and allied agencies to develop alternate ways of instruction for each educational institution. On the other hand, universities that have not yet developed an infrastructure for online learning may encounter obstacles. Many professors and students are wary of implementing online learning methodologies due to the ingrained culture of the traditional educational system. The study's objective was to ascertain how teaching and learning activities were conducted a year after Al Washliyah Labuhanbatu University was closed due to an epidemic. The study employed a mixed-method approach, collecting quantitative and qualitative data using questionnaires. The mixed-method strategy was supplemented with a Google Forms-based online questionnaire distributed to 100 students. Over $75 \%$ of instructors include video conferencing, learning management systems, and instant messaging in their presentations. During Covid-19 at Al Washliyah University, teachers agreed that combining the three platforms reduced obstacles to online learning and increased lecturers' and students' familiarity with the usage of online learning materials.

Keywords: COVID-19, pandemic, online learning

Copyright (c) 2022

Syahraini Ritonga, Witma Novita Atnur, Erlia Utami Panjaitan, Defri Rahmat, Rahmi Syafriyeti

$\triangle$ Corresponding author:

Email : rahmi@univalabuhanbatu.ac.id

DOI : https://doi.org/10.31004/edukatif.v4i1.1743

ISSN 2656-8063 (Media Cetak)

ISSN 2656-8071 (Media Online)

Edukatif : Jurnal Ilmu Pendidikan Vol 4 No 1 Tahun 2022 p-ISSN 2656-8063 e-ISSN 2656-8071 

Witma Novita Atnur, Erlia Utami Panjaitan, Defri Rahmat, Rahmi Syafriyeti

DOI: https://doi.org/10.31004/edukatif.v4i1.1743

\section{INTRODUCTION}

Since the first part of 2020, the coronavirus pandemic has posed a threat to educational institutions worldwide. As a result, several nations, including Indonesia, have established regulations prohibiting all forms of schooling, requiring the government and affiliated entities to offer alternate instructional methods for educational institutions. As a result, traditional classroom learning, and teaching methods were examined and replaced by online learning (Sahir et al., 2021).

Online learning refers to a method of education in which students and lecturers are physically separated and require a delivery system or technology to mediate their contact with learning environments designed to substantially influence learning outcomes. Online teaching platforms improve the interaction between students and teachers (Verawardina et al., 2020). Additionally, several systems like Google Classroom, Zoom, slide, video maker platforms, and Cisco Webex may enhance online teaching and learning.

Since the beginning of the COVID-19 epidemic, about one billion individuals have been quarantined to prevent the virus from spreading further. It is also wreaking havoc on education throughout the world, with the latest UNESCO numbers showing that as of March 23, 2020, around 1.3 billion students were unable to attend school or university. Kids in 1,379,344,914 schools around the country have been affected by school closures, accounting for 80 percent of the world's enrolled students. Localized school closures affect an additional 284 million students (McCarthy, 2020).

Using video conferencing (sometimes referred to as video telephone or telecollaboration) has made it possible for people in different parts of the world to communicate visually and audibly. During the 1990s, videoconferencing services became more affordable and frequently used in educational settings due to technological developments. Google Classroom and Edmodo are two examples of learning management systems (LMS) that may be used to facilitate the distribution and grading of assignments in an asynchronous setting. In addition, instant messaging and social networks are essential for computer and mobile communication nowadays, as they allow for a rapid exchange of messages (McCarthy, 2020).

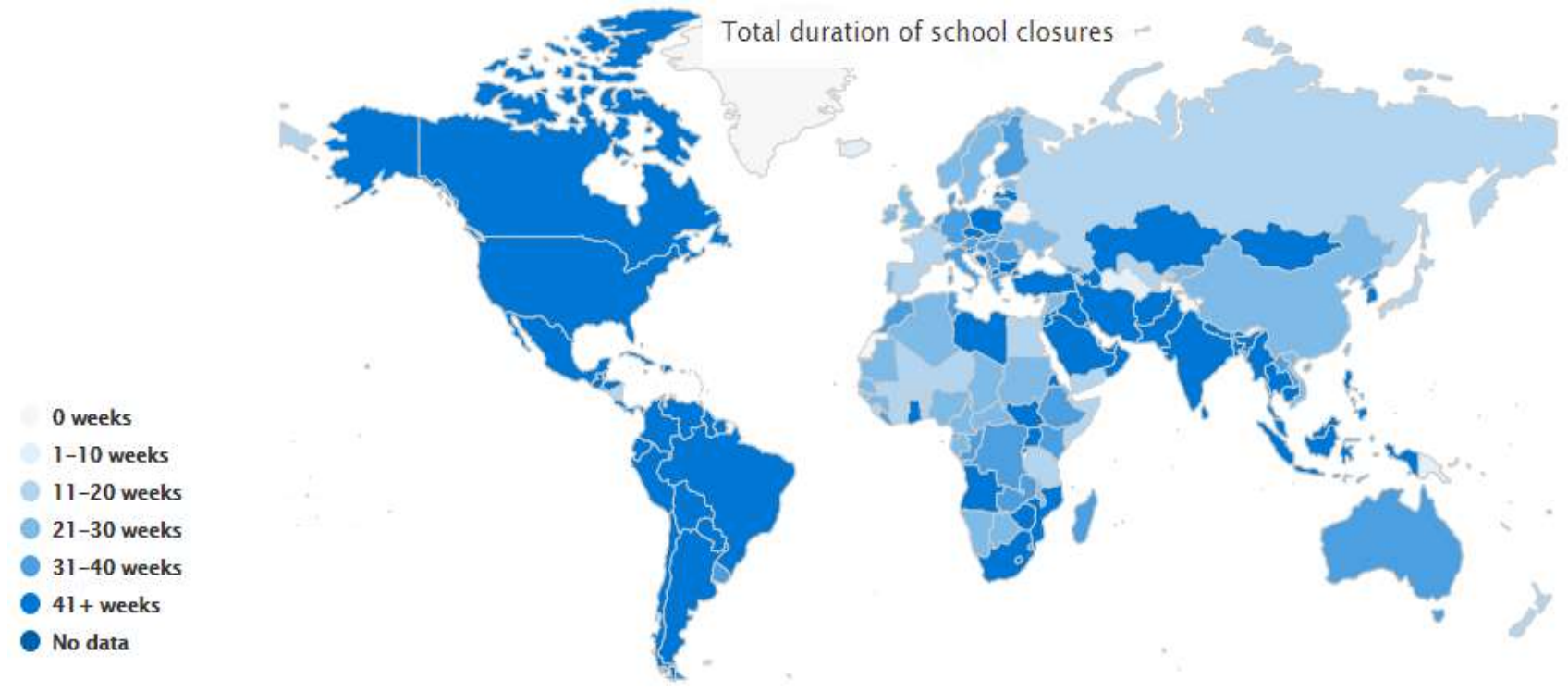

Figure 1. Total duration of school closures (UNESCO, 2021)

Online Learning has been introduced by the Indonesian Ministry of Education and Culture (Kemdikbud) to prevent the proliferation of the Covid-19 for higher education in March 2020. Most Indonesian universities were obliged to establish distance education or online lectures as a result of this regulation. According to a Directorate General of Higher Education (Ditjen Dikti) survey, 98\% of institutions offer online courses. An 
103 A Study of Online Platforms Learning During the Covid-19 Pandemic in College - Syahraini Ritonga, Witma Novita Atnur, Erlia Utami Panjaitan, Defri Rahmat, Rahmi Syafriyeti

DOI: https://doi.org/10.31004/edukatif.v4i1.1743

established online academic infrastructure is not an issue for universities that have used this technology (Samsir et al., 2021) (Edi et al., 2021).

However, those universities that have not yet established an online academic infrastructure will confront problems. Many lecturers and students are apprehensive about employing an online learning technique because of the cultural norms of the educational system. Digital illiteracy is what this ailment is all about. In order to become effective in online learning, both lecturers and students must study hard. A lack of Internet infrastructure and platforms at Indonesia's universities has resulted in a lack of online learning opportunities (Saboowala \& Manghirmalani Mishra, 2021).

According to a survey of students at Wahidyyah Kediri High School, there was a lack of enthusiasm for online learning across all indicators. Practicums in laboratories and other on-campus settings may be preventing some students from completing their coursework entirely through the internet (Firmansyah, 2021). FKIP Mataram University students, on the other hand, found the online learning process challenging, particularly in terms of the teaching and learning process itself, the restricted number of quotas, and the lack of interaction when the online learning process occurred (Turmuzi et al., 2021). While the research on Muhammadiyah Junior High School students 1 Jombang found that online learning has a 62 percent effect on student learning independence, other variables have a 38 percent influence (Sulistyowati \& Amri, 2021).

The findings of a research of 701 students from the Faculty of Business and Economics at Asia Institute of Technology and Business, Malang, revealed that both motivation and learning facilities had a favorable and substantial impact on student learning independence. The more the motivation and comprehensive, practical, and high-quality learning facilities, the greater the student's learning independence. The major impediment to learning is a lack of internet connection/data signals in various places where students dwell, making online lectures sluggish and less appealing (Santoso, 2021). A remarkable 37.4 percent of School counseling students at Cenderawasih University report that online learning has improved their ability to learn independently (Rofi'ah et al., 2021).

The purpose of this study is to identify how teaching and learning activities were undertaken a year after Al Washliyah University Labuhanbatu was closed due to the pandemic. The mixed-method approach was utilized in conjunction with an online questionnaire created on a google form survey and given to 100 students at the University of Al Washliyah Labuhanbatu's Faculty of Teacher Training and Education.

\section{RESEARCH METHOD}

This survey research utilized a mixed-method approach that included both quantitative and qualitative information; the quantitative information was gathered through the use of a questionnaire. The qualitative information was gathered through interviews with lecturers and other experts. An online semi-structured questionnaire and a structured interview were used in this investigation. On a google form survey, there were several options to choose from while filling out the questions. It was possible for respondents to provide additional information if the current information did not match their own personal experiences or preferences. When it comes to obtaining relevant data, the precision and consistency of research tools becomes an important consideration. Experts' opinion and Cronbach's alpha confirmed the validity of the tools used in this investigation (Bordoloi et al., 2021) (Giatman et al., 2019).
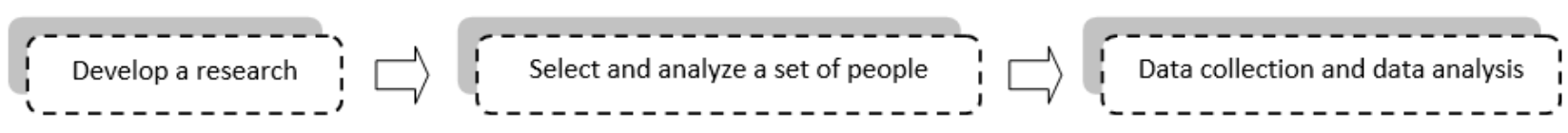

Figure 2. Research Stages

This research was carried out at Universitas Al Washliyah Labuhanbatu. Purposive sampling with a disproportionate stratified procedure was used in this investigation. As a result, a total sample of 100 students and ten lectures from the Faculty of Teacher Training and Education was gathered. The questionnaire link was 
104 A Study of Online Platforms Learning During the Covid-19 Pandemic in College - Syahraini Ritonga, Witma Novita Atnur, Erlia Utami Panjaitan, Defri Rahmat, Rahmi Syafriyeti

DOI: https://doi.org/10.31004/edukatif.v4i1.1743

delivered to responders through WhatsApp, and the data was gathered online. Since a year of remote learning deployment, the online questionnaire identified online learning platforms utilized by lecturers during the Covid-19 epidemic (Syafriyeti et al., 2021).

Furthermore, after collecting student responses, open-ended questions were utilized to interview instructors about their impressions of online media and corroborate students' responses. Finally, professors were questioned through WhatsApp using open-ended questions. Results from questionnaires and interviews were used in this study. Percentage formula was used to calculate the questionnaire findings (Yahya \& Irfan, 2018).

$$
\% \text { response }=\frac{f}{N} \times 100 \%
$$

The dividing of the frequency (f) and the number of participants (N) produces the percentage of the responses indicated in formula 1. Furthermore, interview responses were descriptively examined with narrative interpretation to corroborate students' replies and get lecturers' perspectives on online learning platforms.

\section{RESULT AND DISCUSSION}

Figure 3 shows the percentage of students using video conferences (Zoom and Google Meet), Google Classroom, Edmodo, and WhatsApp or Telegram based on the survey results that were delivered to students.

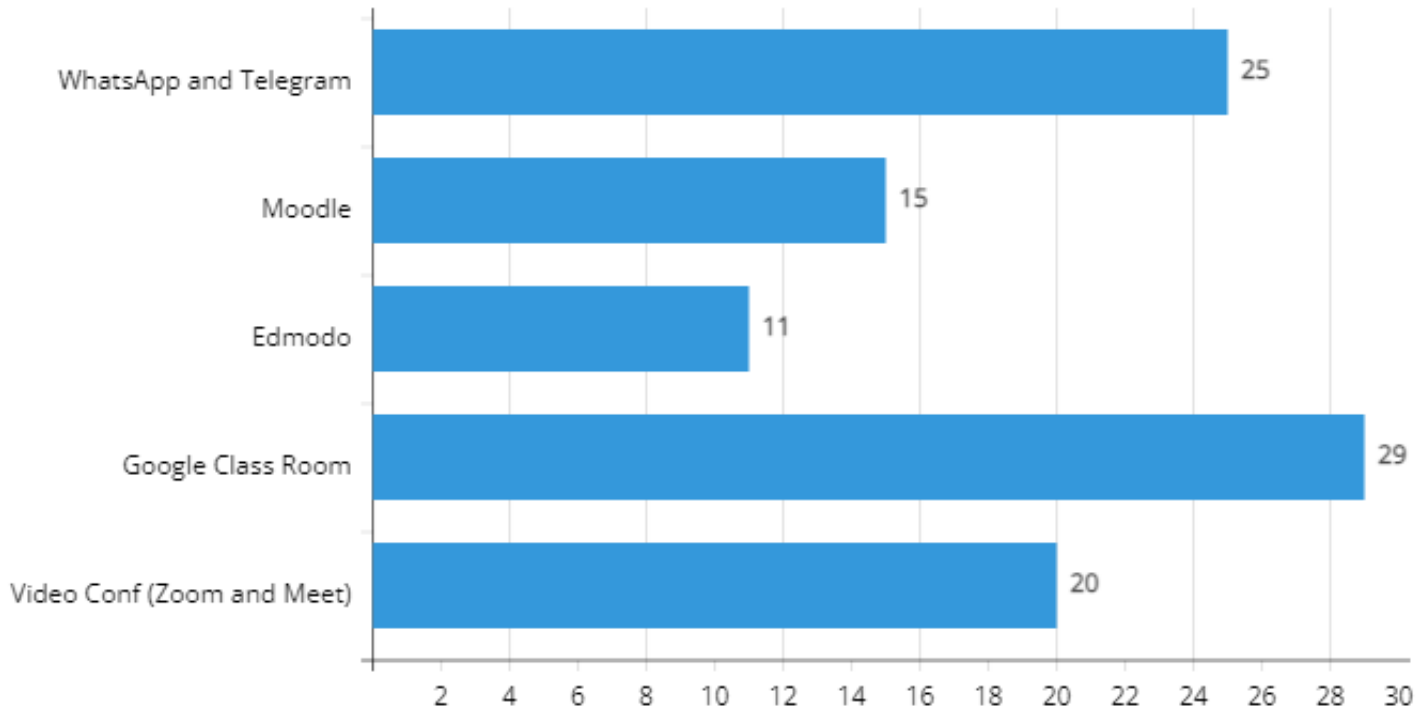

Figure 3. The Percentage of Online Learning Systems

As seen in Figure 3, Google Classroom platforms became the most extensively utilized in remote learning, reaching a peak of $29 \%$. With $25 \%$, WhatsApp or Telegram came in second, while video conferencing followed in third with $20 \%$. On the other side, just $11 \%$ of users used the Edmodo platform, while $15 \%$ used e-Moodle. WhatsApp conversations with lecturers corroborated these findings, and the findings indicated that academics prefer video conferencing because they enable lecturers to discuss lesson contents directly, similar to face-to-face teaching but in a virtual context. Additionally, students were free to clarify any concerns they had regarding the lecturer's explanation (Zhafira et al., 2020).

Additionally, lecturers stated that they chose open-access online platforms since their school is developing its online learning platforms that would be used in the following semester. Additionally, researchers classified data by video conferencing (Zoom and Google Meet), Learning Management Systems (LMS) (Google Classroom and Edmodo), and instant messaging (WhatsApp and telegram), as well as the combination of those platforms in remote learning. Finally, figure 4 illustrates how lecturers utilize platforms. 


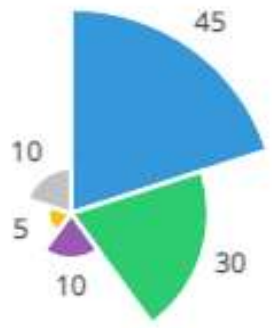

\author{
Video Conf and LMS \\ Video Conf and Instan Messenger \\ Zoom or Meet \\ Moodle or Edmodo \\ WhatsApp or Telegram
}

Figure 4. The Percentage of Online Learning Systems

According to Figure 4, more than $75 \%$ of lecturers include video conferencing, a learning management system, and instant messaging in their lectures. Additionally, lecturers stated in the interview that combining two platforms was beneficial for them, stating that they used instant messaging to tell students about their schedules, video conferencing to clarify lecture material, and an LMS to distribute assignments. Additionally, instant messaging platforms such as WhatsApp make lecturers more accessible and broader in their communication with students and facilitate the formation of discussion groups. Both lecturers and students are constantly monitoring their phones for messages and responding to the arrival sound.

In addition, instant messaging and social networks can facilitate educational outcomes, develop healthy relationships, and promote a sense of belonging, identity building, and self-esteem in the educational arena. In furthermore, the LMS was the best way to use lockdown time, as it allows students to access material at any time and from any location, simplifies creating, empowers learners and teachers alike, communicates information, assignments, post a note, assignments submission, and projects, and simplifies the process of submitting assignments. On the other hand, video conferencing systems are easy to use, allow students to learn in their environment, give them a choice to pick which lectures they want to attend and remove the requirement that students be physically present at the school.

There were 45 percent, and 30 percent of participants who participated in a video conference with LMS, respectively, according to Figure 4. Video conferencing with instant messaging came in at 5\%, followed by LMS. To make their teaching and learning process more efficient and successful, lecturers employ video conferencing, an LMS, and instant messaging.

Teachers can make online learning easier for students by combining these various platforms. For example, a teacher could communicate with students about class schedules via instant messaging and explain lecture materials over a video conference while uploading assignments to a learning management system. The instructor filmed it in a video conference meeting and made it available to students in the LMS or through instant messaging. Since the commencement of the university's shutdown, teachers have constantly been improving their use of online learning to ensure that students receive the best possible education. Both teachers and students are getting increasingly comfortable with online learning, according to teachers.

\title{
CONCLUSION
}

The lecturers used many different sorts of online platforms to assist them in the teaching and learning process. During Covid-19 at Universitas Al Washliyah, the video conference, learning management system, and instant messaging were the most often utilized platforms by instructors in remote learning. The lecturers agreed that using a mix of those three platforms helps to reduce the obstacles to online learning. Furthermore, both lecturers and students are getting increasingly comfortable with the use of online learning resources.

\section{REFERENCE}

Bordoloi, R., Das, P., \& Das, K. (2021). Perception towards online/blended learning at the time of Covid-19 pandemic: an academic analytics in the Indian context. Asian Association of Open Universities Journal, 
106 A Study of Online Platforms Learning During the Covid-19 Pandemic in College - Syahraini Ritonga, Witma Novita Atnur, Erlia Utami Panjaitan, Defri Rahmat, Rahmi Syafriyeti

DOI: https://doi.org/10.31004/edukatif.v4i1.1743

16(1), 41-60. https://doi.org/10.1108/AAOUJ-09-2020-0079

Edi, F., Ambiyar, A., Verawardina, U., \& ... (2021). Improving Lesson Plan Models Using Online-Based in the New Normal Era. EDUTEC: Journal of ....

http://ejournal.ijshs.org/index.php/edu/article/download/109/158

Firmansyah, F. (2021). Motivasi Belajar dan Respon Siswa terhadap Online Learning sebagai Strategi Pembelajaran di Masa Pandemi Covid-19. EDUKATIF : JURNAL ILMU PENDIDIKAN, 3(2), 589-597. https://doi.org/10.31004/edukatif.v3i2.355

Giatman, M., Haq, S., \& Pratama, Y. F. (2019). Effectivity of Online Learning Teaching Materials Model on Innovation Course of Vocational and Technology Education. Journal of Physics: Conference Series, $1387(1), 12131$.

McCarthy, N. (2020). UNESCO: COVID-19 School Closures Have Impacted Nearly 1.4 Billion Students. Forbes. https://www.forbes.com/sites/niallmccarthy/2020/03/24/unesco-covid-19-school-closures-haveimpacted-nearly-14-billion-students-infographic/?sh=6257d7043dd5

Rofi'ah, R. Z., Reba, Y. A., \& Saputra, A. A. (2021). Pengaruh Pembelajaran Online Pada Masa Pandemi Covid-19 Terhadap Kemandirian Belajar Mahasiswa. Coution : Journal of Counseling and Education, 2(2), 39. https://doi.org/10.47453/coution.v2i2.389

Saboowala, R., \& Manghirmalani Mishra, P. (2021). Readiness of In-service Teachers Toward a Blended Learning Approach as a Learning Pedagogy in the Post-COVID-19 Era. Journal of Educational Technology Systems, 50(1), 9-23. https://doi.org/10.1177/00472395211015232

Sahir, S. H., Ramadhana, R. S. A., \& ... (2021). Online learning sentiment analysis during the covid-19 Indonesia pandemic using twitter data. IOP Conference ....

https://iopscience.iop.org/article/10.1088/1757-899X/1156/1/012011/meta

Samsir, Ambiyar, Verawardina, U., Edi, F., \& Watrianthos, R. (2021). Analisis Sentimen Pembelajaran Daring Pada Twitter di Masa Pandemi COVID-19 Menggunakan Metode Naïve Bayes. Jurnal Media Informatika Budidarma, 5(1), 157-163. https://doi.org/10.30865/mib.v5i1.2604

Santoso, R. (2021). Pengaruh Motivasi dan Sarana Belajar Online Terhadap Kemandirian Belajar Mahasiswa FEB Institut Asia di Masa Pandemi Covid-19. Jurnal Penddidikan Ekonomi, 14(1). https://doi.org/http://journal2.um.ac.id/index.php/jpe/article/view/17297

Sulistyowati, S. N., \& Amri, F. (2021). Pengaruh Pembelajaran Online terhadap Kemandirian Belajar Siswa SMP Muhammadiyah 1 Jombang di Masa Pandemi Covid-19. Jurnal Pendidikan Tambusai, 5(2).

Syafriyeti, R., Atnur, W. N., \& Watrianthos, R. (2021). Pengembangan Model Problem-Based Learning Untuk Mengetahui Keterampilan Pembelajaran dan Refleksi Mahasiswa Pendidikan Biologi. BioEduin, 11(2).

Turmuzi, M., Dasing, A. S. H., Baidowi, B., \& Junaidi, J. (2021). Analisis Kesulitan Belajar Mahasiswa Secara Online (E-learning) Selama Masa Pandemi Covid-19. EDUKATIF: JURNAL ILMU PENDIDIKAN, 3(3), 900-910. https://doi.org/10.31004/edukatif.v3i3.482

UNESCO. (2021). Education: From disruption to recovery. UNESCO Institute for Statistics. https://en.unesco.org/covid19/educationresponse

Verawardina, U., Asnur, L., Lubis, A. L., Hendriyani, Y., Ramadhani, D., Dewi, I. P., \& ... (2020). Reviewing online learning facing the Covid-19 outbreak. Talent Development $\backslash \&$ Excellence, 12.

Yahya, S. A., \& Irfan, D. (2018). Pengaruh Penerapan Model Pembelajaran Pjbl Terhadap Hasil Belajar Mata Pelajaran Tkbgt Siswa Kelas X Teknik Mekatronika Smk Negeri 1 Sumatera Barat. VoteTEKNIKA: Jurnal Vocational Teknik Elektronika Dan Informatika, 6(2), 61-74.

Zhafira, N. H., Ertika, Y., \& Chairiyaton. (2020). Persepsi Mahasiswa Terhadap Perkuliahan Daring Sebagai Sarana Pembelajaran Selama Masa Karantina Covid-19. Jurnal Bisnis Dan Kajian Strategi Manajemen. 